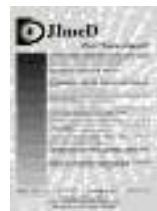

Jurnal Imejing Diagnostik (JImeD) 6 (2020) 47-50

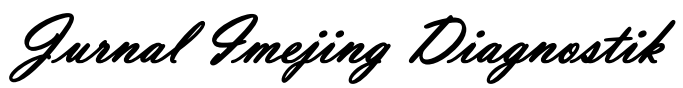

e-ISSN 2621-7457, p-ISSN 2356-301X

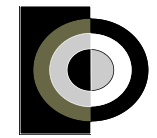

http://ejournal.poltekkes-

smg.ac.id/ojs/index.php/jimed/index

\title{
Rancang Bangun Alat Fiksasi Sekaligus Cassette Holder untuk Pemeriksaan Radiografi Abdomen Proyeksi LLD (Left Lateral Decubitus) pada Pasien non Kooperatif
}

\author{
Agustina Dwi Prastanti, Kevin Ade Juliantino, Ardi Soesilo Wibowo, Siti Daryati \\ Jurusan Teknik Radiodiagnostik dan Radioterapi, Poltekkes Kemenkes Semarang, Indonesia \\ Corresponding author: Agustina Dwi Prastanti \\ Email: tina.atrodepkes17@gmail.com
}

Received: January $30^{\text {th }}, 2020$; Revised: January $31^{\text {th }}, 2020$; Accepted: January $31^{\text {th }}, 2020$

\begin{abstract}
Background: Research on the design of fixation devices as well as cassette holders for projection of abdominal radiography in LLD (left lateral decubitus) in non-cooperative patients is motivated by difficulties in fixing patients and placing tapes by radiographers during LLD (left lateral decubitus) radiographs with non-patient conditions cooperative. The purpose of making a design is to replace the patient's family role in holding patients and tapes during the examination.

Methods: This type of research is applied research. The method used in data collection is designing tools, using tools, testing the performance of tools, testing the function of tools. The performance test and the function test of the tool were carried out directly on the patients at the RSK Radiology Installation Ngesti Waluyo Parakan. The results of the performance test and function test were analyzed based on the check list of respondents regarding the work value of the tool.

Results: The design of this fixation tool consists of a supporting iron component, patient stand, cassette holder, strap strap. The performance test of the tool is in accordance with the specifications of the tool made by the author. Function tests are divided into two, namely function tests based on the technique of using tools and based on the radiograph produced. Function tests based on the use of tools techniques obtained a total work value of 3.1 can be concluded the function of a tool based on the technique of good use.

Conclusions: Function tests based on the resulting radiographs obtained a total work value of 3.33 can be concluded that the function of a tool based on the resulting radiograph is good.
\end{abstract}

Keyword : design; fixation tool; cassette holder; non cooperative

\section{Pendahuluan}

Pemeriksaan radiografi dengan menggunakan sinar-X mempunyai peranan penting terhadap pelayanan kesehatan terutama di bidang diagnostik, yakni untuk mengetahui kelainan-kelainan struktur anatomi tubuh manusia, sehingga dari pemeriksaan tersebut dapat ditegakkan diagnosa dari gangguan fisiologi yang dialami penderita. Disisi lain, penggunaan sinar-X juga dapat menimbulkan efek bahaya radiasi bagi petugas, pasien, maupun keluarga pasien.

Efek radiasi terhadap jaringan dan organ tubuh yang terjadi akibat interaksi langsung ataupun tidak langsung dapat mengakibatkan kerusakan jaringan, organ tubuh dan kegagalan dalam perbaikan DNA ataupun sel. Urutan tingkat sensitivitas organ-organ tubuh manusia yang rentan terhadap radiasi sinar-X adalah organ reproduksi, mata, sumsum tulang, dan kulit (Hall, 2006).

Salah satu tindakan untuk meminimalisasi bahaya radiasi adalah dengan penggunaan alat bantu pemeriksaan radiografi agar masyarakat, petugas, maupun keluarga pasien terhindar dari radiasi sekunder sinar-x selama pemeriksaan berlangsung. Keberadaan dari alat bantu pemeriksaan sangat dibutuhkan pada beberapa pemeriksaan. Alat bantu tersebut bertujuan untuk membantu kinerja radiografer dalam memposisikan pasien maupun kaset sebaik mungkin sehingga akan diperoleh hasil radiograf yang maksimal dari suatu pemeriksaan radiografi.

Berbagai macam alat bantu pemeriksaan banyak terdapat di dunia radiologi, antara lain cassette holder, tam-em board,sponges and soft bags, piggo-stat, tape, compression band (Bontrager, 2014). 
Kegunaan alat bantu tersebut ada yang bersifat spesifik yaitu hanya dapat digunakan pada pemeriksaan tertentu saja sebagai contoh pigg-ostat yang merupakan alat bantu pemeriksaan proyeksi erect abdomen dan thorax pediatrik, tamem board sebagai alat bantu pemeriksaan untuk pasien pediatrik pada posisi supine. Terdapat pula alat bantu pemeriksaan yang dapat digunakan untuk membantu sebagian besar pemeriksaan radiografi bagian tubuh manusia seperti cassette holder, sandbag dan softbag. Alat-alat tersebut memiliki fungsi yang terpisah sebagai alat fiksasi tersendiri ataupun sebagai cassette holder tersendiri.

Berdasarkan pengamatan peneliti selama mengerjakan pemeriksaan ditemukan banyak radiografer yang mengalami kesulitan dalam memposisikan kaset pada saat pemeriksaan dengan kasus pasien non kooperatif. Dimana kondisi pasien non kooperatif adalah kondisi dimana pasien tidak bisa diajak bekerjasama dalam pemeriksaan, misalnya kondisi pasien yang tidak sadarkan diri, ataupun kondisi dimana pasien sukar untuk diposisikan maupun diberi instruksi dikarenakan kondisi klinis yang diderita pasien. Contohnya pada pasien dengan permintaan foto abdomen LLD (left lateral decubitus) dengan indikasi abdomen akut. Biasanya pada kasus-kasus tersebut radiografer meminta tolong kepada keluarga pasien untuk memegangi kaset agar tetap tegak lurus horizontal dengan arah sinar. Tentu saja hal ini sangat tidak efektif dalam aspek proteksi radiasi, karena keluarga pasien juga ikut mendapatkan radiasi sekunder sinar-x yang tidak berguna.

Berdasarkan hal tersebut penulis ingin memecahkan masalah dengan merancang sebuah alat bantu modifikasi fiksasi dan juga sekaligus cassette holder, untuk memudahkan radiografer dalam memposisikan pasien dan juga untuk meletakkan kaset sinar-x. Dimana selama ini belum ada alat bantu pemeriksaan radiologi yang berfungsi ganda sebagai alat fiksasi dan sekaligus cassette holder. Alat bantu ini bertujuan untuk keselamatan radiasi terhadap masyarakat, petugas, dan keluarga pasien.

\section{Metode}

Jenis penelitian ini merupakan salah satu penelitian terapan (applied research) dengan membuat rancang bangun alat fiksasi sekaligus cassette holder untuk pemeriksaan radiografi abdomen proyeksi LLD (left lateral decubitus) pada pasien non kooperatif, sekaligus pengujian alat bantu tersebut.

\section{Hasil dan Pembahasan}

Desain Rancang Bangun Alat Fiksasi sekaligus Cassette Holder Untuk Pemeriksaan Radiografi Abdomen Proyeksi LLD (Left Lateral Decubitus) Pada Pasien Non Kooperatif.

Tabel 1. Spesifikasi Alat Bantu Modifikasi Penyangga Kaset Sinar X

\begin{tabular}{|l|l|l|}
\hline No & $\begin{array}{l}\text { Bagian- } \\
\text { bagian Alat }\end{array}$ & \multicolumn{1}{|c|}{ Keterangan } \\
\hline $\mathbf{1}$ & $\begin{array}{l}\text { Besi } \\
\text { Penyangga }\end{array}$ & $\begin{array}{l}\text { Bahan dasar dari besi } \\
\text { penyangga adalah plat besi } \\
\text { yang memiliki panjang 25 } \\
\mathrm{cm}, \text { lebar 8 cm, dan tebal 4 } \\
\text { mm. }\end{array}$ \\
\hline $\mathbf{2}$ & $\begin{array}{l}\text { Busa } \\
\text { Sterofoam }\end{array}$ & $\begin{array}{l}\text { Busa sterofoam ini terbuat } \\
\text { dari busa yang berukran } \\
\text { panjang 60 cm, lebar 40 cm, } \\
\text { dan memiliki tebal 8 cm. }\end{array}$ \\
\hline $\mathbf{3}$ & $\begin{array}{l}\text { Cassette } \\
\text { holder }\end{array}$ & $\begin{array}{l}\text { Terdiri dari bagian besi } \\
\text { penyangga dan plat } \\
\text { berbentuk letter L dengan } \\
\text { panjang 60 cm, dengan } \\
\text { lebar 2 cm, dan tinggi } 1 \mathrm{~cm} .\end{array}$ \\
\hline $\mathbf{4}$ & Tali Strap & $\begin{array}{l}\text { Merupakan tali yang } \\
\text { berfungsi untuk memfiksasi } \\
\text { pasien supaya dapat } \\
\text { diposisikan LLD, tali ini } \\
\text { dilengkapi dengan pengunci } \\
\text { yang terbuat dari plastik. }\end{array}$ \\
\hline
\end{tabular}

$1 \quad$ Plat Besi

Penulis memilih bahan plat besi dengan ketebaalan $4 \mathrm{~mm}$, dengan lebar $8 \mathrm{~cm}$ sebagai bahan dasar untuk bagian besi penyangga dan juga cassette holder. Penggunaan plat besi ini dikarenakan bahannya yang mudah didapatkan, kuat, dan juga mudah dibentuk.

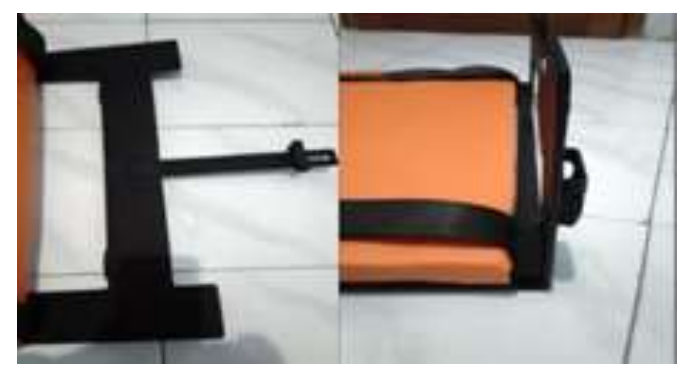

Gambar 1. Besi penyangga dan cassette holder

\section{Busa Sterofoam}

Busa sterofoam ini digunakan sebagai alas untuk tidur pasien, penulis menggunakan busa yang bersifat agak keras sehingga ketika di beri beban pasien tidak mengempis. 


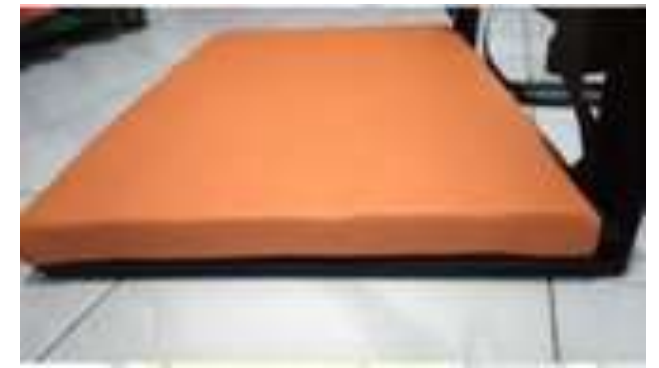

Gambar 2. Busa Sterofoam

\section{Tali Strap}

Tali strap ini berfungsi sebagai penahan dan juga fiksasi supaya pasien tetap dalam posisi LLD dan tidak mengalami pergerakan selama pemeriksaan.

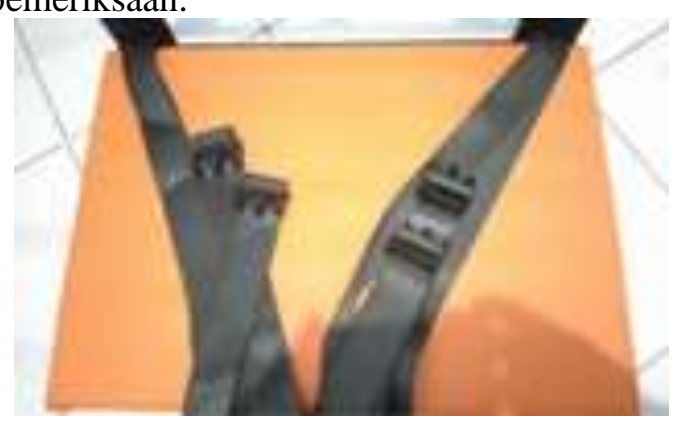

Gambar 3. Tali strap

4 Pengunci

Pengunci ini terbuat dari bahan plastik yang berfungsi untuk mengunci tali strap sehingga pasien dapat terfiksasi secara maksimal

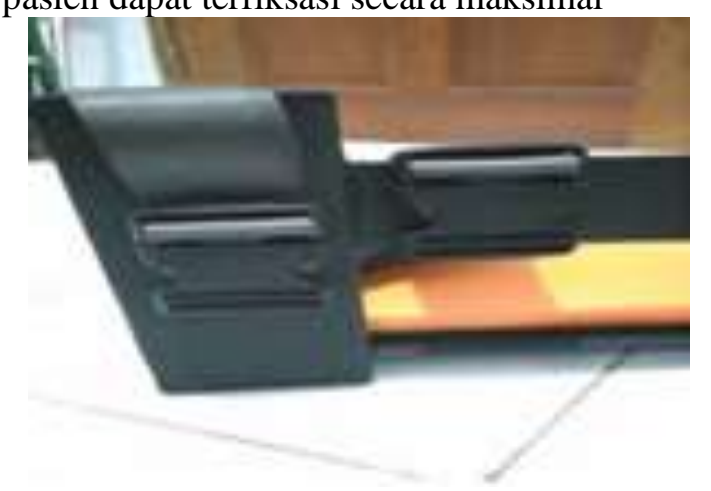

Gambar 4. Pengunci tali strap

Desain Rancang Bangun Alat Fiksasi sekaligus Cassette Holder Untuk Pemeriksaan Radiografi Abdomen Proyeksi LLD (Left Lateral Decubitus) Pada Pasien Non Kooperatif.

Alat fiksasi sekaligus cassette holder untuk pemeriksaan radiografi abdomen proyeksi $L L D$ (left lateral decubitus) pada pasien non kooperatif merupakan alat bantu yang digunakan untuk mempermudah kerja radiografer dalam memfiksasi posisi pasien pada saat pemeriksaan abdomen proyeksi LLD. Serta memudahkan radiografer menempatkan kaset sehingga tidak perlu meminta tolong kepada keluarga pasien untuk memegangi kaset dan pasien pada saat pemeriksaan berlangsung. Sehingga keluarga pasien tidak terkena paparan radiasi.

Bahan baku alat ini sebagian besar terbuat dari plat besi, alasan digunakannya plat besi sebagai bahan pembuatan alat ini karena plat besi memiliki bentuk yang pipih dan kuat sehingga mudah digunakan dan dapat menopang berat tubuh pasien. Pada alat fiksasi ini menggunakan plat besi dengan ketebalan $4 \mathrm{~mm}$, kemudian pada masing-masing bagian dipotong sesuai dengan ukuran yang telah ditentukan menggunakan gerinda potong dan di las sesuai dengan sketsa gambar yang telah dibuat.

Pada bagian dudukan pasien terbuat dari bahan busa sterofoam sehingga dapat memberikan kenyamanan kepada pasien. Alat ini juga dilengkapi dengan tali strap yang dapat dipanjangkan dan dipendekkan menyesuaikan ukuran tubuh pasien.

Cara kerja alat fiksasi ini cukup mudah, yaitu dengan meletakkan alat diatas meja pemeriksaan kemudian menempatkan kaset dan mengatur posisi pasien lalu mengikatkan tali strap di bagian pengunci.

\section{Hasil Pengujian Alat Fiksasi Sekaligus Cassette Holder Untuk Pemeriksaan Radiografi Abdomen Proyeksi LLD (Left Lateral Decubitus) Pada Pasien Non Kooperatif. \\ Uji kinerja alat fiksasi sekaligus cassette holder} untuk pemeriksaan radiografi abdomen proyeksi LLD (left lateral decubitus) pada pasien non kooperatif dilakukan berdasarkan spesifikasi alat yang dibuat oleh penulis. Sesuai pengujian kinerja alat yang telah dilakukan, didapatkan hasil bahwa semua komponen alat sudah sesuai dengan spesifikasi yang dibuat dan siap digunakan serta diaplikasikan di lapagan.

Uji fungsi alat dibagi menjadi dua, yaitu berdasarkan teknik penggunaan alat dan berdasarkan radiograf yang dihasilkan. Uji fungsi alat dilakukan di Instalasi Radiologi RSK Ngesti Waluyo Parakan terhadap pasien oleh responden dengan menggunakan alat fiksasi sekaligus cassette holder untuk pemeriksaan radiografi abdomen proyeksi $L L D$ (left lateral decubitus) pada pasien non kooperatif.

Berdasarkan penilaian responden dan telah dilakukan penghitungan total nilai kerja, didapatkan dengan hasil skor sebesar 3,1 sehingga dapat disimpulkan bahwa fungsi alat berdasarkan teknik penggunaan alat fiksasi sekaligus cassette holder untuk pemeriksaan radiografi abdomen proyeksi LLD (left lateral decubitus) pada pasien non kooperatif adalah baik. 
Berdasarkan penilaian responden dan telah Nova Rahman, 2009. Radiofotografi, Edisi dilakukan penghitungan total nilai kerja, didapatkan dengan hasil skor sebesar 3,33 sehingga dapat ke-1, Universitas Baiturrahman : Padang.

disimpulkan bahwa fungsi alat berdasarkan Pearce, Evelyn C. 2009. Anatomi dan radiograf yang dihasilkan oleh alat fiksasi sekaligus Fisiologi untuk Paramedis. Jakarta : cassette holder untuk pemeriksaan radiografi PT. Gramedia.

abdomen proyeksi LLD (left lateral decubitus) pada Soekidjo Notoatmodjo, 2012. Metodologi pasien non kooperatif adalah baik.

\section{SIMPULAN}

Penelitian Kesehatan. Jakarta : Rineka Cipta.

Desain rancang bangun alat fiksasi sekaligus cassette holder untuk pemeriksaan radiografi abdomen proyeksi $L L D$ (left lateral decubitus) pada pasien non kooperatif tersusun atas 4 komponen, yakni : besi penyangga, dudukan pasien, cassette holder, tali strap. Cara kerja alat fiksasi ini dengan cara diletakkan diatas meja pemeriksaan, pasang kaset pada cassette holder, posisikan pasien diatas alat, fiksasi pasien menggunakan tali strap. Alat fiksasi sekaligus cassette holder untuk pemeriksaan radiografi abdomen proyeksi $L L D$ (left lateral decubitus) pada pasien non kooperatif sudah memenuhi uji kinerja sesuai dengan spesifikasi alat dan sudah memenuhi uji fungsi alat, serta telah siap diaplikasikan di lapangan dan untuk penggunaan alat dapat berfunsi dengan baik, untuk di lapangan sendiri belum ada alat buatan pabrikan untuk pemeriksaan tersebut.

\section{DAFTAR PUSTAKA}

Ballinger, 2016. Radiographic Positioning and Radiological Procedure, Edisi ke-9, Volume III. P.W.Mosby Inc : Missouri.

Bontrager, 2014. Tex book of Radiographic Positioning and Related Anatomy, Edisi ke-5, Mosby Inc :St. Louis, Amerika.

Bushong, 2013. Radiologic Science for Technologists, Edisi ke-10, Mosby Inc :St. Louis

Freddyantoro, 2015. Rancang bangun cassette holder pada proyeksi pemeriksaan abdomen left lateral decubitus (LLD).

Hall, 2006. Radiobiology for the radiologist, Edisi ke-6, Philadelphia, Amerika.

Masrochah dkk, (2015), Rancang Bangun Alat Bantu Fiksasi Dengan Penanda Waktu Eksposi Untuk Pemeriksaan Radiografi Abdomen Akut. 